\title{
THE SHORT-TERM EFFECTS OF CHYMOPAPAIN ON INTERVERTEBRAL DISCS
}

\author{
P. DOLAN, M. A. ADAMS, W. C. HUTTON
}

From the Polytechnic of Central London

\begin{abstract}
Cadaveric lumbar dises were injected with chymopapain and subjected to a series of mechanical tests over a period of up to 19 hours. Dises from the same spine injected with saline were used as controls. The results showed that chymopapain had no measurable effect on the mechanical properties of the disc apart from the increased height and stiffening caused by fluid injection. Another series of tests on isolated pieces of disc material showed that chymopapain could reduce the size of prolapsed nuclear material by $24 \%$ in one hour and by $80 \%$ in 48 hours.
\end{abstract}

It is concluded that, in the short-term, chymopapain has a negligible effect on the mechanics of a disc but it can reduce the size of any prolapsed nuclear material with which it comes in contact.

The effectiveness of chemonucleolysis in relieving symptoms is still disputed (Martins et al. 1978; Javid, Nordby and Ford 1983; Fraser 1984). Uncertainty with regard to the efficacy of the technique might be resolved if the precise nature of the effect of chymopapain on the disc could be determined.

Laboratory tests have shown that chymopapain breaks down and effectively dissolves the proteoglycans of homogenised human nucleus pulposus, but has little effect on collagen (Stern and Smith 1967). In the intact disc the proteoglycans of the nucleus pulposus form a hydrated gel in which the collagen fibrils are embedded. The proteoglycans themselves are large molecules built up from proteins and glycosaminoglycans (GAGs) and it is the hydrophilic properties of the GAGs which cause disc tissue to swell in the presence of water. Chymopapain probably breaks up the proteoglycan molecules, so enabling the relatively small GAGs and the associated water to diffuse out of the disc. The remaining tissue is reduced in size and has less tendency to swell in water. With homogenised material, this process is essentially complete within six hours (Stern and Smith 1967). With whole discs it may take longer, since the enzyme has a reduced surface area to bind on to and, in addition, the collagen network of the annulus prevents gross swelling

P. Dolan, PhD, Research Fellow

M. A. Adams, PhD, Research Fellow

W. C. Hutton, DSc, Professor

Faculty of Engineering and Science, School of Mechanical and Computer Aided Engineering, The Polytechnic of Central London, 115 New Cavendish Street, London W1M 8JS, England.

Requests for reprints should be sent to Professor W. C. Hutton.

(C) 1987 British Editorial Society of Bone and Joint Surgery $0301-620 \mathrm{X} / 87 / 3102 \$ 2.00$ and the easy release of GAGs. When chymopapain was injected into the discs of young live dogs, it took 7 to 9 days to have its full effect as indicated by the reduction in disc height (Garvin and Jennings 1973). In humans, where the discs are larger and generally more collagenous than those of young animals, the disc height continues to decrease until about one month after injection (Bitz and Ford 1977). Most of this delay is probably due to the slow rate at which the breakdown products escape from the disc.

The limited biomechanical data has been used to try to explain the clinical effects of chymopapain. One theory proposed that the enzyme dissolves the proteoglycans of nucleus pulposus material within the disc, as described above, so that the nucleus shrinks and loses its capacity to swell in water; it is then unable to exert a high radial pressure on the annulus and consequently any annular protrusion is reduced. This assumes that human nucleus pulposus can be efficiently dissolved by chymopapain and that this action will cause decompression of the irritated nerve root. We find it difficult to understand this explanation, since reducing nuclear volume leads to increased radial bulging, not less (Brinkmann and Horst 1985). Another theory proposes that, if chymopapain is injected into a prolapsed disc that has an extrusion of nuclear material, then the enzyme will reduce the size of the extrusion. Here it is assumed that an extruded lump of nucleus pulposus can be reached and then digested by the injected enzyme, even though such material may be highly collagenous. Another possibility is that chymopapain has a direct chemical effect on an irritated nerve root; this is mere speculation, but it does offer an explanation for the large number of patients who obtain relief of symptoms either immediately or very shortly 


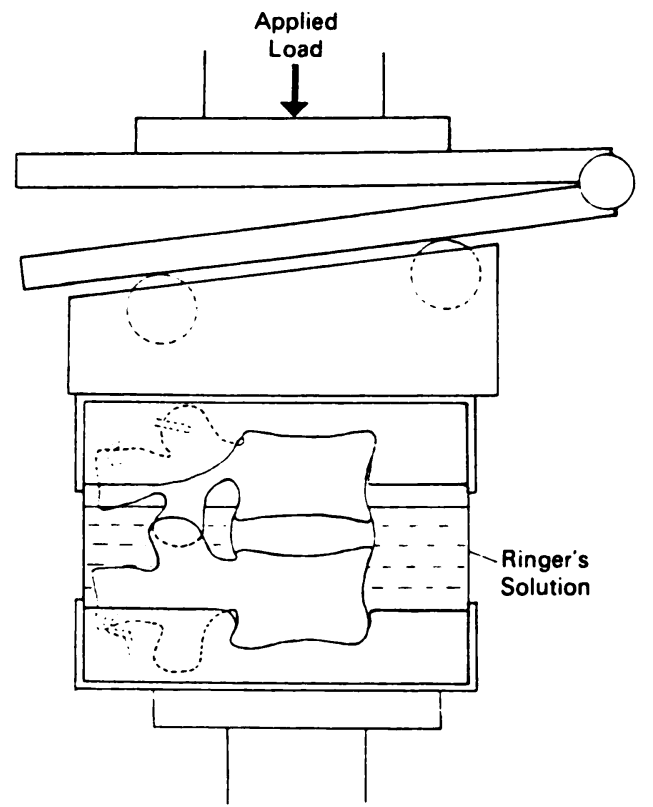

Fig. 1

The apparatus used to test the motion segments.

after injection (Smith and Brown 1967; McCulloch 1980).

In order to clarify these issues, we decided to try to discover what effect chymopapain has on human cadaveric discs. Three separate experiments were carried out: the first two examined the effect of chymopapain on the mechanical behaviour and swelling pressure of whole discs, while the third examined the effects of the enzyme on isolated pieces of disc tissue. The term "swelling pressure" as used here should not be confused with the hydrostatic pressure in the nucleus pulposus which can be measured by intradiscal needle techniques; the swelling pressure is a measure of the tissue's chemical affinity for water, while the hydrostatic pressure is a real "physical pressure" inside the nucleus.

In the case of the first two experiments, the tests were carried out at room temperature $\left(22^{\circ} \mathrm{C}\right)$ rather than body temperature $\left(37^{\circ} \mathrm{C}\right)$ because this was more convenient and separate tests had shown that, considering the duration of our experiments, it made no significant difference.

\section{MATERIALS AND METHODS}

Cadaveric material and testing procedures. Lumbar spines were removed at routine necropsies from subjects aged between 22 and 60 years (mean 41 years) who had been fully mobile before death. These spines were dissected into two motion segments, each consisting of two vertebrae and the intervening soft tissue (see Adams and Hutton 1983 for details). The remaining lumbar discs were excised and kept at $-20^{\circ} \mathrm{C}$ for subsequent biochemical tests.
After dissection, the motion segments to be used in the first experiment were injected with up to $1 \mathrm{ml}$ of radiopaque fluid (Conray 400, May and Baker) and discograms were obtained in the sagittal and transverse planes (see Adams, Dolan and Hutton 1986 for details). The discograms showed whether the discs were ruptured or intact.

After discography, each motion segment was set in two cups of mildly exothermic dental plaster and loaded on a Mayes servo-controlled testing machine as shown in Figure 1. The machine was capable of applying static, dynamic or oscillatory loads and the angle plate could be adjusted to cause the specimen to flex. An x-y plotter recorded the applied compressive force and the vertical movement of the ram of the testing machine. Once loaded on the machine, the specimens were surrounded by a bath of Ringer's solution in order to simulate in vivo conditions. During the experiments, the bath was drained (and subsequently re-filled) whenever the specimen was unloaded.

Experiment I: the effect of chymopapain on the mechanical properties of discs. Fifteen pairs of motion segments were tested. One from each pair was eventually injected with chymopapain (supplied as Discase by Travenol Laboratories) and the other with saline as a control. In the group injected with chymopapain one specimen was at $\mathrm{Ll}-2$, three at L2-3, three at L3-4, five at L4-5 and three at L5S1. In the control group, three were at L1-2, four at L2-3, four at L3-4, three at L4-5 and one at L5-S1.

Initially each motion segment was loaded in compression for one hour at a load equivalent to body weight. This was done in order to dissipate the excess fluid present as a result of injecting the radiopaque fluid. At the end of this time the facet joints, ligamentum flavum and the supraspinous and interspinous ligaments were cut through, leaving only the disc intact. The following tests were then carried out on each motion segment:

1. The compressive stiffness of the disc was measured by loading the specimen in compression to $3000 \mathrm{~N}$ at a rate of $1 \mathrm{~mm} / \mathrm{s}$. The compressive stiffness was given by the tangent to the load-deformation curve at $3000 \mathrm{~N}$ load. 2. The specimen's resistance to bending was then measured by applying a load offset to the centre of rotation (Adams, Hutton and Stott 1980).

After these two mechanical tests a compressive load of $200 \mathrm{~N}$ was applied to the disc to simulate the load when lying supine in life (Nachemson 1981). Whilst still loaded, the discs were injected, one from each pair with chymopapain and the other with the same volume of saline as a control. Many of the discs would accept very little fluid at discography, probably because they were already in a highly hydrated state after being unloaded in the body for several hours before removal. Therefore we decided to use twice the recommended concentration of chymopapain $(0.8 \%)$ and only attempted to inject up to $1.0 \mathrm{ml}$ of the enzyme. This ensured that all discs received 
a dose of chymopapain equivalent to that used clinically.

After injection, motion segments were reloaded in compression for 18 hours at a load equivalent to body weight, and the total height loss was recorded. The compressive load was then reduced to $200 \mathrm{~N}$ and the uptake of fluid over the next hour was determined by measuring the subsequent increase in disc height. At the end of this hour, Tests 1 and 2 were repeated. In Test 2 , each motion segment was flexed to the same angle as before, and the bending moment was again determined.

Before being removed from the testing machine, the discs were injected with up to $1 \mathrm{ml}$ of a mixture of radiopaque fluid and dye (aniline blue) and a second discogram was then taken. After discography all the discs were re-frozen for cutting. Each disc was cut in half in the sagittal plane. One half was sectioned into $3 \mathrm{~mm}$ slices in the transverse plane and the other half sectioned into $3 \mathrm{~mm}$ slices in the sagittal plane.

Experiment II: the effect of chymopapain on disc swelling pressure. Five pairs of motion segments were tested. In the group injected with chymopapain one was at $\mathrm{Ll}-2$, one at L2-3, two at L4-5 and one at L5-S1. In the control group two were at L2-3, two at L3-4 and one at L4-5.

Before injection, each motion segment was initially creep-loaded for two hours at a load of $3000 \mathrm{~N}$ in order to expel fluid and raise the swelling pressure (this is abnormally low in post-mortem specimens which have been in an unloaded state). By increasing the swelling pressure in this way we felt we would more easily be able to detect any subsequent effect caused by chymopapain. At the end of the two-hour loading period the facet joints, ligamentum flavum and the supraspinous and interspinous ligaments were cut through and the following tests were carried out:

1. The disc swelling pressure was measured: this was defined as the load at which there was no net inflow or outflow of fluid across the boundary of the disc, so that the disc height remained constant for at least five minutes.

2. The discs were placed under a compressive load of $200 \mathrm{~N}$ and injected with up to $1 \mathrm{ml}$ of chymopapain (or saline). The swelling pressure was then measured immediately to determine the effect of fluid injection.

3. The discs were again loaded at $3000 \mathrm{~N}$ for another hour and the reduction in disc height was measured.

4. The disc swelling pressure was again measured.

On each occasion when the swelling pressure was measured, the resistance of the disc to bending and compression was also measured as described above.

Experiment IIIA: the effect of chymopapain on isolated nucleus pulposus. For this experiment 16 discs which were excised from specimens during dissection were used. Three pieces of nucleus pulposus each $100 \mathrm{mg}( \pm 1 \mathrm{mg})$ in weight were removed from the central part of each disc. One of these pieces was dried to constant weight at $50^{\circ}$ to $60^{\circ} \mathrm{C}$ to obtain a control value for the dry weight.

The remaining two pieces of nucleus were immersed
Table I. Results of Experiment I*

\begin{tabular}{|c|c|c|}
\hline & $\begin{array}{l}\text { Chymopapain- } \\
\text { injected discs }\end{array}$ & $\begin{array}{l}\text { Saline- } \\
\text { injected discs }\end{array}$ \\
\hline Number of motion segments tested & 15 & 15 \\
\hline $\begin{array}{l}\text { Injected volume of either chymopapain } \\
\text { or saline }(m l)\end{array}$ & $0.81 \pm 0.21$ & $0.83 \pm 0.22$ \\
\hline Height increase after injection $(\mathrm{mm})$ & $0.44 \pm 0.21$ & $0.54 \pm 0.33$ \\
\hline $\begin{array}{l}\text { Height loss during 18-hour } \\
\text { creep-loading }(\mathrm{mm})\end{array}$ & $2.48 \pm 0.58$ & $2.30 \pm 0.45$ \\
\hline $\begin{array}{l}\text { Height gain during one hour } \\
\text { creep-loading at } 200 \mathrm{~N}(\mathrm{~mm})\end{array}$ & $0.18 \pm 0.15$ & $0.21 \pm 0.18$ \\
\hline $\begin{array}{l}\text { Increase in compressive stiffness } \\
\text { after creep-loading (per cent) }\end{array}$ & $2.1 \pm 15.2$ & $3.3 \pm 10.9$ \\
\hline $\begin{array}{l}\text { Reduction in bending moment resisted } \\
\text { after creep-loading (per cent) }\end{array}$ & $76.2 \pm 11.3$ & $76.0 \pm 17.7$ \\
\hline Mean flexion angle & $8.4^{\circ} \pm 1.3^{\circ}$ & $7.7^{\circ} \pm 1.2^{\circ}$ \\
\hline
\end{tabular}

* Paired $t$-tests showed no significant difference in any of the parameters measured

at room temperature $\left(22^{\circ} \mathrm{C}\right)$ in either $0.4 \%$ chymopapain or in physiological $(0.9 \%)$ saline; $5 \mathrm{ml}$ of solution was used per $100 \mathrm{mg}$ of tissue. From the supernatant solution $200 \mu$ l "aliquots" (samples) were removed after one, six and 48 hours. These aliquots were immediately frozen and later assayed for uronic acid content using a modified carbazole technique (Bitter and Muir 1962). The concentration of uronic acid in the supernatant third was taken as a measure of the proteoglycan loss from the disc tissue.

At the end of 48 hours the pieces of disc were removed from the solution, blotted until the surface was dry and the final wet weight recorded. The dry weight of the disc pieces was also determined as described above. The dried disc pieces were then digested overnight at $60^{\circ} \mathrm{C}$ using papain (Sigma Laboratories). The resulting solution was assayed for uronic acid to enable the final uronic acid content of the disc pieces to be estimated.

Experiment IIIB : the effect of chymopapain on prolapsed disc material. Cadaveric motion segments were dissected, set in dental plaster and loaded on a servo-controlled testing machine as previously described. The discs were induced to prolapse by applying high compressive loads to the motion segments while they were wedged in hyperflexion. This technique has been described in detail elsewhere (Adams and Hutton 1982). Ten prolapses were obtained in this way. Into three of these discs $1 \mathrm{ml}$ of chymopapain $(0.8 \%)$ dyed with aniline blue was injected; these discs were photographed both before and after injection to show the passage of the injected enzyme. From the remaining seven discs the prolapsed material was removed, weighed and then immersed in saline for 90 hours at $37^{\circ} \mathrm{C}$. This was done in order to simulate the in vivo situation where newly extruded disc material is free to interact with body fluid.

To follow the time course of any swelling, the wet weight of the prolapsed material was measured after one, 
four, 24, 48, 72 and 90 hours of immersion. After 90 hours, when the wet weight showed little further change, the prolapsed material was immersed in $0.4 \%$ chymopapain at $37^{\circ} \mathrm{C}$. Again the wet weight was measured at one, four, 24 and 48 hours. After 48 hours the prolapsed material was dried to constant weight and then digested overnight using papain as described earlier. The resulting solution, as well as the final saline and chymopapain solutions, were each assayed for uronic acid. This enabled us to estimate the relative loss of proteoglycans brought about by leaching and by the enzyme.

\section{RESULTS}

Each disc treated with chymopapain was compared with its saline control. Significant differences between the results were measured at the $5 \%$ level using Student's $t$ test for matched pair data.

A summary of the results of Experiment $I$ is shown in Table I. There was no significant difference between the chymopapain discs and the control discs in any of the parameters measured, either before or after injection. Because of this lack of difference we decided not to include a full table of results. When discs were sectioned at the end of the test, several of the chymopapaininjected discs showed evidence of macroscopic changes in structure: the nucleus pulposus was unusually soft and only loosely bound together and, in two cases, small holes were observed (Fig. 2). Similar effects were not observed in any of the control discs.

The results of Experiment II are summarised in Table II. Injection of chymopapain or saline caused an immediate rise in disc height and a fall in swelling pressure, and the extent of these changes was similar in both groups. Subsequent loading of the discs at $3000 \mathrm{~N}$

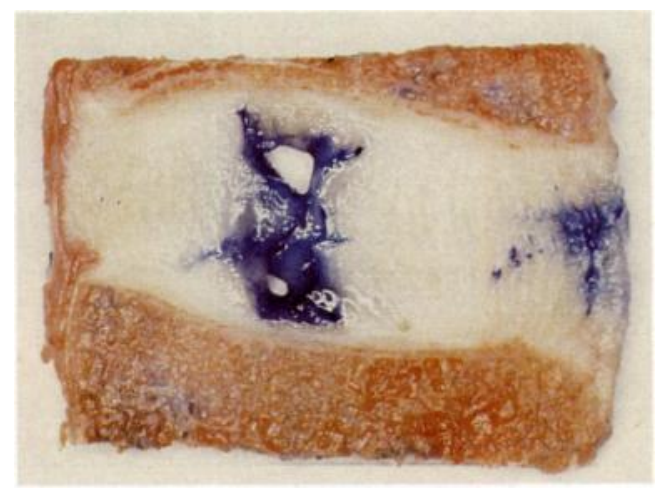

Fig. 2

Sagittal section from a 43-year-old disc (L3-4) after chymopapain injection. In this disc the nucleus tended to collapse on sectioning and holes appeared (note superior part)

caused the swelling pressure to rise and the disc height to fall. After an hour at this load the swelling pressure of the chymopapain-injected discs was lower than that of the controls, although there was no significant difference in height loss (Table II).

The results of Experiment IIIA are shown in Table III. Chymopapain reduced the wet weight of pieces of nucleus pulposus, while saline increased it. All the immersed disc pieces showed a significant reduction in dry weight compared to the control, and the extent of this reduction was greater with chymopapain. The uronic acid loss from the chymopapain-immersed disc pieces after one, six and 48 hours was $48.0 \pm 25.2 \%, 83.0 \pm$ $43.1 \%$ and $91.4 \pm 6.2 \%$ respectively. The corresponding values for saline were $46.3 \pm 24.2 \%, 73.2 \pm 21.2 \%$ and $87.8 \pm 7.9 \%$. The final uronic acid loss (and hence proteoglycan loss) at 48 hours was greater with chymopapain.

Table II. Results of Experiment II, showing changes in swelling pressure and disc height after injection of either chymopapain or saline

Saline-injected dises

\begin{tabular}{|c|c|c|c|c|c|c|c|c|c|c|c|}
\hline \multirow[b]{2}{*}{ Specimen } & \multirow[b]{2}{*}{$\begin{array}{l}\text { Injected } \\
\text { volume } \\
(m l)\end{array}$} & \multicolumn{3}{|c|}{ Swelling pressure } & \multirow[b]{2}{*}{$\begin{array}{l}\text { Height loss } \\
\text { during } \\
\text { creep- } \\
\text { loading } \\
(\mathrm{mm})\end{array}$} & \multirow[b]{2}{*}{ Specimen } & \multirow[b]{2}{*}{$\begin{array}{l}\text { Injected } \\
\text { volume } \\
\text { (ml) }\end{array}$} & \multicolumn{3}{|c|}{ Swelling pressure } & \multirow[b]{2}{*}{$\begin{array}{l}\text { Height loss } \\
\text { during } \\
\text { creep- } \\
\text { loading } \\
(\mathrm{mm})\end{array}$} \\
\hline & & $\begin{array}{l}\text { Before } \\
\text { injection } \\
\text { (newtons) }\end{array}$ & $\begin{array}{l}\text { Immediately } \\
\text { after injection } \\
\text { (\% pre- } \\
\text { injected } \\
\text { value) }\end{array}$ & $\begin{array}{l}\text { After creep- } \\
\text { loading* } \\
\text { (\% pre- } \\
\text { injected } \\
\text { value) }\end{array}$ & & & & $\begin{array}{l}\text { Before } \\
\text { injection } \\
\text { (newtons) }\end{array}$ & $\begin{array}{l}\text { Immediately } \\
\text { after injection } \\
(\% \text { pre- } \\
\text { injected } \\
\text { value })\end{array}$ & $\begin{array}{l}\text { After creep- } \\
\text { loading" } \\
(\% \text { pre- } \\
\text { injected } \\
\text { value })\end{array}$ & \\
\hline M35 L4-5 & 50.85 & 1850 & 7.6 & 94.1 & 0.95 & M35 L2- & -30.85 & 1845 & 9.7 & 80.0 & 0.95 \\
\hline M38 L2-3 & 30.85 & 2060 & 7.3 & 102.9 & 0.89 & M38 L4- & -50.85 & 2050 & 6.6 & 95.6 & 0.91 \\
\hline M47 L2-3 & 31.0 & 1925 & 1.3 & 104.9 & 0.80 & M47 L4- & -51.0 & 2220 & 2.0 & 87.8 & 0.69 \\
\hline M52 L3-4 & 41.0 & 1555 & 29.6 & 103.0 & 0.92 & M52 L5- & -S1 1.0 & 1400 & 13.4 & 93.1 & 0.94 \\
\hline M53 L3-4 & 41.0 & 1110 & 38.8 & 84.9 & 0.99 & M53 Ll- & -21.0 & 1200 & 38.1 & 80.7 & 1.17 \\
\hline Mean & & 1700 & 16.9 & 98.0 & 0.91 & & & 1743 & 14.0 & 87.4 & 0.93 \\
\hline $\begin{array}{l}\text { Standard } \\
\text { deviation }\end{array}$ & & 378 & 16.3 & 8.4 & 0.07 & & & 431 & 14.1 & 7.1 & 0.17 \\
\hline
\end{tabular}

- At $3000 \mathrm{~N}$ for one hour 
Table III. Results of Experiment IIIA, showing the wet weight, dry weight and uronic acid content of disc tissue after 48 hours' immersion in either chymopapain or saline

\begin{tabular}{|c|c|c|c|c|c|c|}
\hline \multirow[b]{2}{*}{ Spectmen } & \multicolumn{3}{|c|}{ Saline-immersed disc pleces } & \multicolumn{3}{|c|}{ Chymopapain-immersed discs } \\
\hline & $\begin{array}{l}\text { Final wet weight } \\
\text { ( } \% \text { initial value) }\end{array}$ & $\begin{array}{l}\text { Final dry weight } \\
\text { (\% control) }\end{array}$ & $\begin{array}{l}\text { Uronic acid loss } \\
\text { (\% initial value) }\end{array}$ & $\begin{array}{l}\text { Final wet weight } \\
\text { (\% initial value) }\end{array}$ & $\begin{array}{l}\text { Final dry weight } \\
\text { (\% control) }\end{array}$ & $\begin{array}{l}\text { Uronic acid loss } \\
\text { (\% intitial value) }\end{array}$ \\
\hline F22 L3-4 & 77.3 & 17.6 & 97.1 & 46.8 & 10.3 & 97.6 \\
\hline M23 L4-5 & 133.9 & 18.4 & 97.4 & 32.3 & 23.5 & 95.6 \\
\hline F24 L1-2 & 142.3 & 33.8 & 91.8 & 82.8 & 22.1 & 93.7 \\
\hline F26 L3-4 & 145.1 & 47.5 & 86.9 & 64.2 & 11.2 & 95.3 \\
\hline M35 L1-2 & 116.3 & 29.2 & 95.1 & 27.6 & 15.1 & 88.0 \\
\hline M35 Ll-2 & 147.3 & 40.3 & 89.3 & 72.4 & 17.7 & 93.6 \\
\hline M35 L3-4 & 121.3 & 26.3 & 95.1 & 81.8 & 20.4 & 95.7 \\
\hline M35 L3-4 & 143.6 & 43.6 & 89.0 & 58.3 & 32.9 & 88.5 \\
\hline M42 L3-4 & 122.2 & 54.7 & 86.2 & 64.9 & 23.9 & 93.3 \\
\hline F43 L4-5 & 169.2 & 42.3 & 85.8 & 135.2 & 26.1 & 94.4 \\
\hline M45 L3-4 & 122.4 & 46.5 & 81.9 & 71.2 & 24.4 & 92.4 \\
\hline F47 L3-4 & 136.0 & 59.2 & 90.0 & 67.0 & 31.2 & 88.6 \\
\hline M51 L3-4 & 150.6 & 41.4 & 91.7 & 114.3 & 26.4 & 94.7 \\
\hline M51 L3-4 & 166.1 & 59.5 & 72.2 & 103.6 & 37.4 & 84.7 \\
\hline M52 L2-3 & 181.1 & 53.1 & 69.9 & 68.8 & 54.8 & 72.9 \\
\hline M52 L2-3 & 144.4 & 51.1 & 85.5 & 51.5 & 25.4 & 90.8 \\
\hline Mean & 138.7 & 41.5 & 87.8 & 71.4 & 25.2 & 91.4 \\
\hline $\begin{array}{l}\text { Standard } \\
\text { deviation }\end{array}$ & 24.4 & 13.3 & 7.9 & 28.2 & 10.8 & 6.2 \\
\hline
\end{tabular}

Table IV. Results of Experiment IIIB, after immersion in saline and then chymopapain

\begin{tabular}{|c|c|c|c|c|c|c|c|}
\hline \multirow[b]{2}{*}{ Specimen } & \multicolumn{2}{|c|}{$\begin{array}{l}\text { Wet weight after immersion } \\
\text { in } 0.9 \% \text { saline }\end{array}$} & \multicolumn{3}{|c|}{$\begin{array}{l}\text { Wet weight after sabsequent immersion } \\
\text { in } 0.4 \% \text { chymopapain }\end{array}$} & \multirow[b]{2}{*}{$\begin{array}{l}\text { Uronic acid loss after } \\
\text { saline immersion } \\
\text { (\% initial value) }\end{array}$} & \multirow[b]{2}{*}{$\begin{array}{l}\text { Uronic acid lost by } \\
\text { chymopapain immersion } \\
\text { (\% initial value) }\end{array}$} \\
\hline & $\begin{array}{l}4 \text { hours } \\
\text { (\% initial } \\
\text { nalue) }\end{array}$ & $\begin{array}{l}90 \text { hours } \\
\text { (\% initial } \\
\text { salue) }\end{array}$ & $\begin{array}{l}1 \text { hour } \\
\text { (\% initial } \\
\text { value) }\end{array}$ & $\begin{array}{l}24 \text { hours } \\
\text { (\% initial } \\
\text { value) }\end{array}$ & $\begin{array}{l}48 \text { hours } \\
\text { (\% initial } \\
\text { value) }\end{array}$ & & \\
\hline F24 L2-3 & 267 & 157 & 91 & 60 & 38 & 94.3 & 1.4 \\
\hline F24 L2-3 & 239 & 97 & 63 & 20 & 14 & 95.1 & 1.9 \\
\hline M38 L1-2 & 220 & 125 & 96 & 12 & 11 & 92.9 & 3.5 \\
\hline F47 L5-S1 & 271 & 197 & 157 & 54 & 42 & 84.8 & .5 .7 \\
\hline M51 L1-2 & 202 & 167 & 167 & 58 & 37 & 89.2 & 6.5 \\
\hline M52 L1-2 & 181 & 77 & 46 & 24 & 22 & 90.5 & 6.3 \\
\hline M52 L3-4 & 188 & 120 & 94 & 27 & 25 & -- & -- \\
\hline Mean & 224 & 134 & 102 & 36 & 27 & 91.1 & 4.2 \\
\hline $\begin{array}{l}\text { Standard } \\
\text { deviation }\end{array}$ & 36 & 42 & 45 & 20 & 12 & 3.8 & 2.3 \\
\hline
\end{tabular}




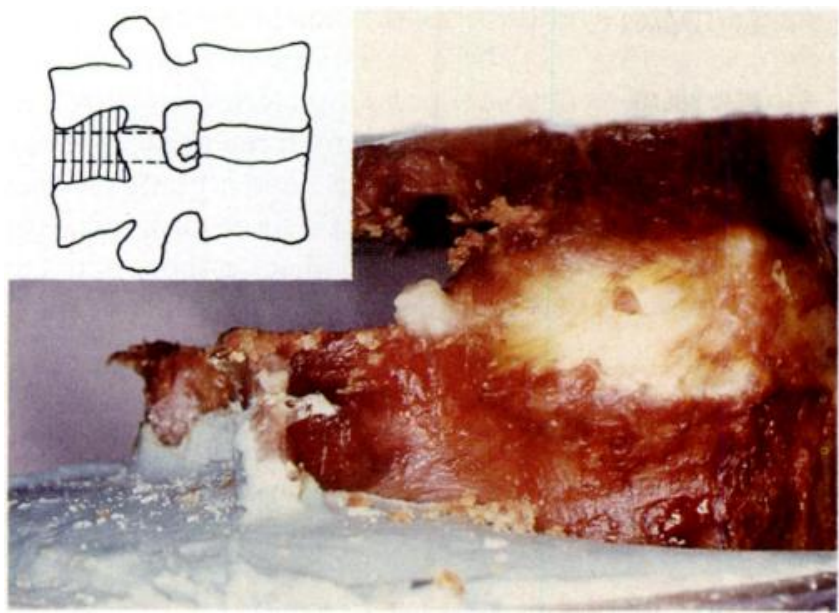

Fig. 3

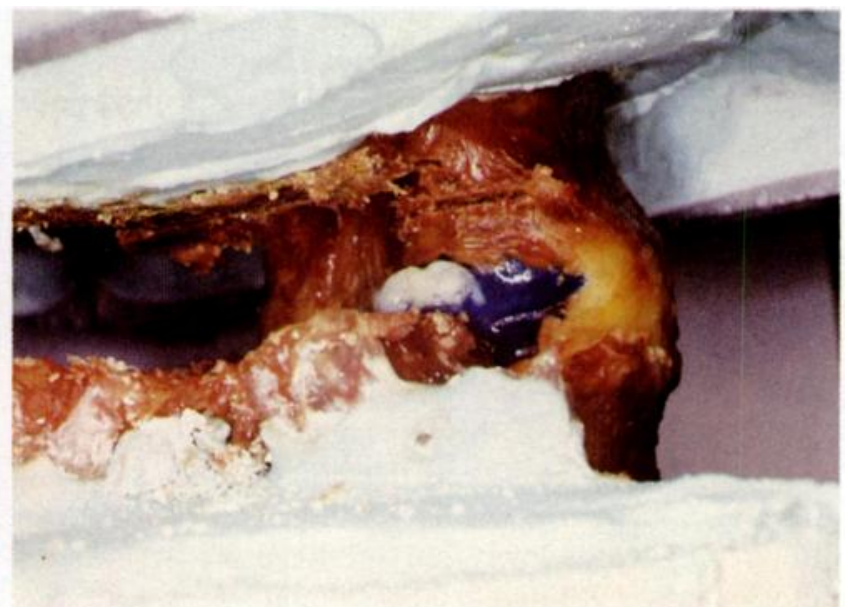

Fig. 4

A posterior prolapse induced in the laboratory before injection of chymopapain (Fig. 3) and after injection (through the anterior annulus) of chymopapain mixed with aniline blue (Fig. 4). The inset shows where the ligaments and apophyseal joints were cut through before the photographs were taken.

In Experiment IIIB, when chymopapain was injected into a newly prolapsed disc, it flowed down the fissure to reach the displaced nuclear material (Figs 3 and 4). This occurred immediately upon injection in each of the three discs injected. Prolapsed nuclear material from the other seven specimens swelled up in saline to between two and three times its original size after one hour, reaching its maximum size after approximately four hours (Figs 5 and 6, Table IV). After this time the wet weight began to fall and continued to do so until approximately $\mathbf{9 0}$ hours, when there was little further change. At this time the disc pieces had lost between $85 \%$ and $95 \%$ of their initial uronic acid as a result of leaching. Nevertheless, five out of the seven pieces of prolapsed material were still markedly swollen when compared to their original wet weight at the time of prolapse (Fig. 7).
When the prolapsed material was removed from the saline and placed in chymopapain, its wet weight was reduced by an average of $24 \%$ after one hour and $80 \%$ after 48 hours (Fig. 8) (note that these reductions are relative to the wet weight after saline immersion, whereas in Table IV all weights are given relative to the weight immediately after prolapse). Chymopapain also caused a further reduction in the uronic acid (proteoglycan) content so that after 48 hours only $3 \%$ to $9 \%$ remained.

\section{DISCUSSION}

This has been a long and complicated experiment, but the results enable us to give a concise account of the short-term effects of chymopapain on human discs.

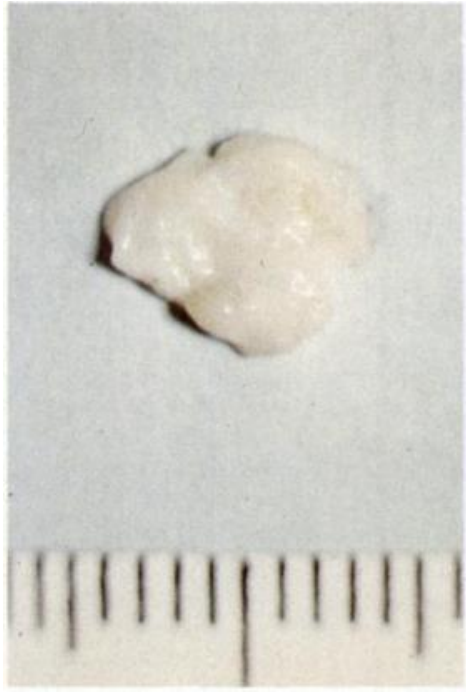

Fig. 5

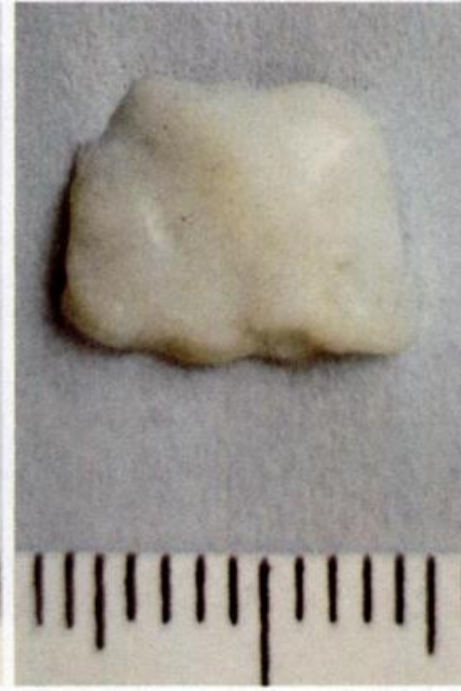

Fig. 6

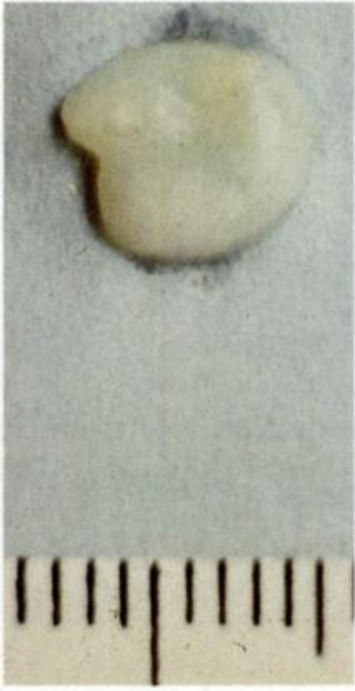

Fig. 7

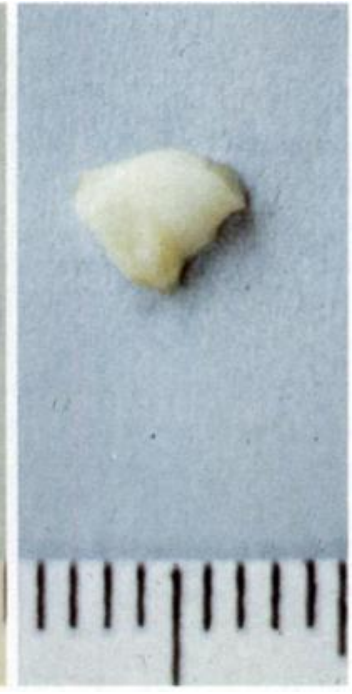

Fig. 8

Figure 5-Displaced disc material was removed at the time of prolapse. Figures 6 and 7 - The disc tissue after it had been allowed to swell up in saline: Figure 6 shows the tissue at its maximum wet weight after four hours and Figure 7 after 90 hours when marked leaching had occurred. Subsequent immersion of the disc material in chymopapain for 48 hours brought about a marked reduction in wet weight (Fig. 8).

The wet tissue in Figure 6 weighed more than that in Figure 7 and that in Figure 8 weighed the least. 
As chymopapain is injected, the disc height rises, its swelling pressure falls (Experiment II) and it bulges less (Brinkmann and Horst 1985); these are simply hydraulic effects that can be obtained just as well with saline. One hour later the swelling pressure is slightly lower because of the specific action of the enzyme. However, the mechanical properties of the disc are not altered much after one hour, or even after 18 hours (Experiment I), and a similar result has recently been reported by Brinckmann and Horst (1986). By 18 hours the enzyme has broken down some of the proteoglycans of the nucleus pulposus (Fig. 2). However, the broken-down products (GAGs) are themselves large molecules which can diffuse only very slowly out of the disc. In life this diffusion process probably takes several weeks, since it is only after this time that the height of the disc and its mechanical properties are significantly altered, according to animal experiments (Wakano et al. 1983) and radiographic follow-up studies on human patients (Bitz and Ford 1977).

Chymopapain can have a much more rapid effect on prolapsed disc material. When injected into a prolapsed disc the enzyme solution flows down the fissure and has a good chance of reaching any extruded fragment of nucleus pulposus. This happened with each of our three prolapsed discs in Experiment IIIB, but in life the extruded fragment may be harder to reach. Once it reaches the nuclear pulp, chymopapain can reduce its size by about $24 \%$ in one hour, and by $80 \%$ after 48 hours (Experiment IIIB).

This account of chymopapain's action was tested on cadaveric discs, but it almost certainly applies to the discs of living people. Let us now consider how well it fits in with clinical experience. The immediate relief of symptoms experienced by many patients can be attributed to the hydraulic effects of fluid injection into the disc, causing increased height and less bulging. Other shortterm relief obtained by patients may well be due to the fact that chymopapain reduces the size of an extruded fragment of nucleus pulposus, even after leaching has taken place. Those patients who show improvement after several months are not so straightforward, but this is beyond the scope of the present experiment.

The swelling and leaching of disc tissue in saline observed in Experiment III is interesting in its own right. These processes have been described before from a biochemical standpoint (Urban and Maroudas 1981) but the physical changes in the tissues may be more important clinically. When a disc prolapses, any extruded nuclear pulp will swell up to about $220 \%$ of its initial size in about four hours (Fig. 6). Leaching will then reduce its size over the next 86 hours to about $130 \%$ of its initial size (Fig. 7). These variations in size will cause variations in mechanical pressure exerted on surrounding tissues. This could explain why some patients report that their back pain and sciatica have a gradual onset. Conclusion. Chymopapain has little short-term mechanical effect on the intervertebral disc, although it can reduce its swelling pressure by a small amount. It can be effective in reducing the size of prolapsed nuclear material provided it reaches such material.

This work is supported by a grant from the Arthritis and Rheumatism Council. Our discograms were taken by the staff of the Radiography Department at the Royal National Orthopaedic Hospital.

\section{REFERENCES}

Adams MA, Hutton WC. The effect of fatigue on the lumbar intervertebral disc. J Bone Joint Surg [Br] 1983;65-B:199-203.

Adams MA, Hutton WC, Stott JRR. The resistance to flexion of the lumbar intervertebral joint. Spine 1980;5:245-53.

Adams MA, Hutton WC. Prolapsed intervertebral disc: a hyperflexion injury. Spine 1982;7:184-91.

Adams MA, Dolan P, Hutton WC. The stages of disc degeneration as revealed by discograms. J Bone Joint Surg [Br] 1986;68-B:36-41.

Bitter T, Muir HM. A modified uronic acid carbazole reaction. Anal Biochem 1962;4:330-4.

Bitz DM, Ford LT. An evaluation of narrowing following intradiskal injection of chymopapain. Clin Orthop 1977;129:191-5.

Brinckmann $\mathbf{P}$, Horst $\mathbf{M}$. The influence of vertebral body fracture, intradiscal injection, and partial discectomy, on the radial bulge and height of human lumbar discs. Spine 1985;10:138-45.

Brinckmann P, Horst M. Short-term biomechanical effects of chymopapain injection: an in vitro investigation of human lumbar motion segments. Clin Biomech 1986;1:14-9.

Fraser RD. Chymopapain for the treatment of intervertebral disc herniation: the final report of a double-blind study. Spine $1984 ; 9: 815-8$.

Garvin PJ, Jennings RB. Long-term effects of chymopapain on intervertebral disks of dogs. Clin Orthop 1973;92:281-95.

Javid MJ, Nordby EJ, Ford LT, et al. Safety and efficacy of chymopapain (Chymodiactin) in herniated nucleus pulposus with sciatica. JAMA 1983;249:2489-94.

Martins AN, Ramirez A, Johnston J, Schwetschenau PR. Double-blind evaluation of chemonucleolysis for herniated lumbar discs: late results. J Neurosurg 1978;49:816-27.

MeCulloch JA. Chemonucleolysis: experience with 2000 cases. Clin Orthop 1980;146:128-35.

Nachemson AL. Disc pressure measurements. Spine 1981 ;6:93-7.

Smith L, Brown JE. Treatment of lumbar intervertebral disc lesions by direct injection of chymopapain. J Bone Joint Surg [Br] 1967;49-B : 502-19.

Stem IJ, Smith L. Dissolution by chymopapain in vitro of tissue from normal or prolapsed intervertebral disks. Clin Orthop 1967;50:269-77.

Urban JP, Maroudas A. Swelling of the intervertebral disc in vitro. Connect Tissue Res 1981;9:1-10.

Wakano K, Kasman R, Chao EY, Bradford DS, Oegema TR. Biochemical analysis of canine intervertebral discs after chymopapain injection: a preliminary report. Spine 1983;8:59-68. 